\title{
INFLUENCE OF COLOUR NET SHADING ON QUANTITY AND QUALITY OF SWEET PEPPER YIELD
}

\author{
HAJNALKa DARÁzSI LEDÓNÉ
}

\author{
TÉSZ-ÉSZ Nonprofit Kft- DélKerTÉSZ \\ Szarvasi út 3/b, 6600 Szentes, Hungary \\ ledone@delkertesz.hu
}

\begin{abstract}
Sweet pepper (Capsicum annum L.) is one of the main cultivated vegetable species in Hungary mostly produced under plastic tunnel by unheated technology. Sweet pepper plants could suffer high temperature and radiation during summer season. However, photoselective-shading nets can provide a new tool for light quality manipulation and support the plant development and fruit quality. The effect of shading colour nets depends on natural light conditions and other environment factors; therefore it is necessary to evaluate the shading technology. Hungarian sweet pepper variety was grown in South-East part of Hungary under plastic tunnels using different colour nets, as white, yellow, green and red, for shading in 2013. Results of trial proved that green colour shading net usually decrease the yield, while yellow and red nets can increase the yield and the fruit quality of Hungarian type sweet pepper. Growers have to care the shading intensity of the net, which should not be higher than 35-40\%. Colour shading nets can be placed onto the plastic tunnels just after the planting.
\end{abstract}

Keywords: photoselective net, shading, Capsicum annuum L., fruit quality

\section{INTRODUCTION}

Using photoselective net in greenhouse technologies of vegetable crops have been widespread in the Mediterranean area since the early 2000s. SHAHAK and co-workers announced first, that the different coloured nets, as red, yellow, blue, grey and pearl give additional affect to horticulture indoor production (SHAHAK ET AL., 2004). Comparing traditional black shade nets with coloured nets in pepper production in Israel increased productivity and was cleared in total fruit yields. During a three-year trial under red, yellow and pearl nets pepper yield was higher by $115-135 \%$ to control thanks to mainly the more fruit number per plant. Authors found that photoselective nets can modify the shading quality both by light dispersion and spectral composition (SHAHAK ET AL. 2008). Measuring the reflectance of sunlight by spectrometer SHAHAK and co-workers (2009) found different spectral composition by each shading net. While the black net transmitted light normal way $(300-850 \mathrm{~nm})$, the colour nets exhibited spectral cut-off below $580 \mathrm{~nm}$ (red), $510 \mathrm{~nm}$ (yellow), or $380 \mathrm{~nm}$ (pearl). Similar photon flux densities of different wavelength resulted different rates of leaf photosynthesis, consequently the same amount of PAR supplied by different assimilation light might result in different biomass production (IEPEREN, 2012). Photosynthetic activity and leaf characteristics of sweet pepper grown under different colour nets were studied and cleared, so that photoselective shading can differently affect the leaf parameters and activities (KONG ET AL., 2012). During ten year collaboration between Polysack Plastic Industries Ltd. and Volcani Institute in Israel a new colour net product, ChromatiNet ${ }^{\circledR}$ was developed. Nets were evaluated in wide range of trials in several countries and climate regions. Currently the leading ChromatiNet ${ }^{\circledR}$ product is red net (GANELEVIN, 2008). SANTANA and co-workers (2012) used red and blue photoselective screens from Polysack to investigate productivity of red and yellow fruit colour sweet pepper varieties in Brazil. Screened productions showed more intensive stem growth, less number of leaves and fruits compared with field 
condition. The fruit losses caused by sunscald were much less $(5 \%)$, than in control field $(35 \%)$.

In Hungary KovÁCS and co-workers (2011) investigated the effect of commercially used green shading net on Hungarian type sweet pepper production under plastic tunnel for the first time. They found significant losses comparing the yield with the results of uncovered plots. Photon flux density and spectral range of four colour Raschel net: white, red, yellow and green (produced by Hungarian firm) were measured on plastic tunnels in 2011-2012. In both years photon flux density was the highest under plastic tunnel covered with additional red net, compared to measures in open field during the summer season, while green shading caused significantly much more light loss (KovÁCS, 2012). During the same trial spectral reflectance and SPAD values on 'Kapia' type red sweet pepper leaves were also measured. It was found, that the leaves at the same age and position responded to different light quality the highest values at middle of July under red net (LEDÓNÉ ET AL., 2013). Sweet pepper yield quantity and quality have been evaluated in Hungary under plastic tunnel unheated production since 2010 (LEDÓNÉ, 2011).

The aim of this study is to summarise the yield results of Hungarian type sweet pepper produced under plastic tunnels covered by photoselective shading nets in South East part of Hungary in 2013.

\section{MATERIAL AND METHOD}

Unheated greenhouse trial was carried out near Hódmezővásárhely, in South East part of Hungary in 2013. Separate plastic tunnels were covered with coloured shading nets having $100 \mathrm{~m}^{2}$ surfaces by each. White (W), yellow1 (Y1), yellow2 (Y2), green (G), red (R) Raschel nets serving 35\% shading intensity provided by the Első Magyar Kenderfonó Ltd. were investigated beside uncovered control tunnel. ChromatiNet ${ }^{\circledR}$ - red (CNR) with $40 \%$ shading intensity was additionally used too. Plastic tunnels were covered by shading nets just after the planting. Hungarian type ivory conical pepper variety, Galga (ZKI) was planted into the tunnels on the $18^{\text {th }}$ of April. The grower used traditional pepper growing technology applying mainly natural fertilizer (Orgevit) during the production season and some leaf fertilizers in some cases. Watering system was put over the plants and the water supply was satisfied according to the plants' demand. The average amount of water got out was $364 \mathrm{~mm}$, while the uncovered control had $370 \mathrm{~mm}$ and CNR tunnel had $322 \mathrm{~mm}$ during the season. Number of hours of sunshine was $25 \%$ more during the season in 2013 than it was the average between 1971-2010 (http1). The harvest period started the last week of July and ended the last week of October, meaning 10 fold harvests. Fruits were measured by weight and by size at harvest time. Based on the results of fruit classification and yield income was calculated using the market information served by DélKerTÉSZ in 2013. The statistical analyses were conducted by Microsoft ${ }^{\circledR}$ Excel 2007 Analysis Toolpak (Microsoft Corp., Redmond, Washington). The data are presented as mean \pm standard deviation $(n=3)$.

\section{RESULTS}

Summarizing the totally harvested sweet pepper fruits there were high differences in the yield among tunnels covered by shading nets of different colour (Figure 1). It was clear, that production under green colour net resulted almost $3 \mathrm{~kg} / \mathrm{m}^{2}$ less yield than in Control plot. The highest yield was measured in CNR plot, followed by control and yellow2 tunnels. 
Taking notice the share of fuits among different quality (Figure 2), CNR net had favourable effect on production of extra fruits of 'Galga' in 2013. Galga produced the most $1^{\text {st }}$ class fruits under the green net. Regarding the amount of fruits suffered by blossom end rot (BER) was not too high, that problem was not considerable in 2013.

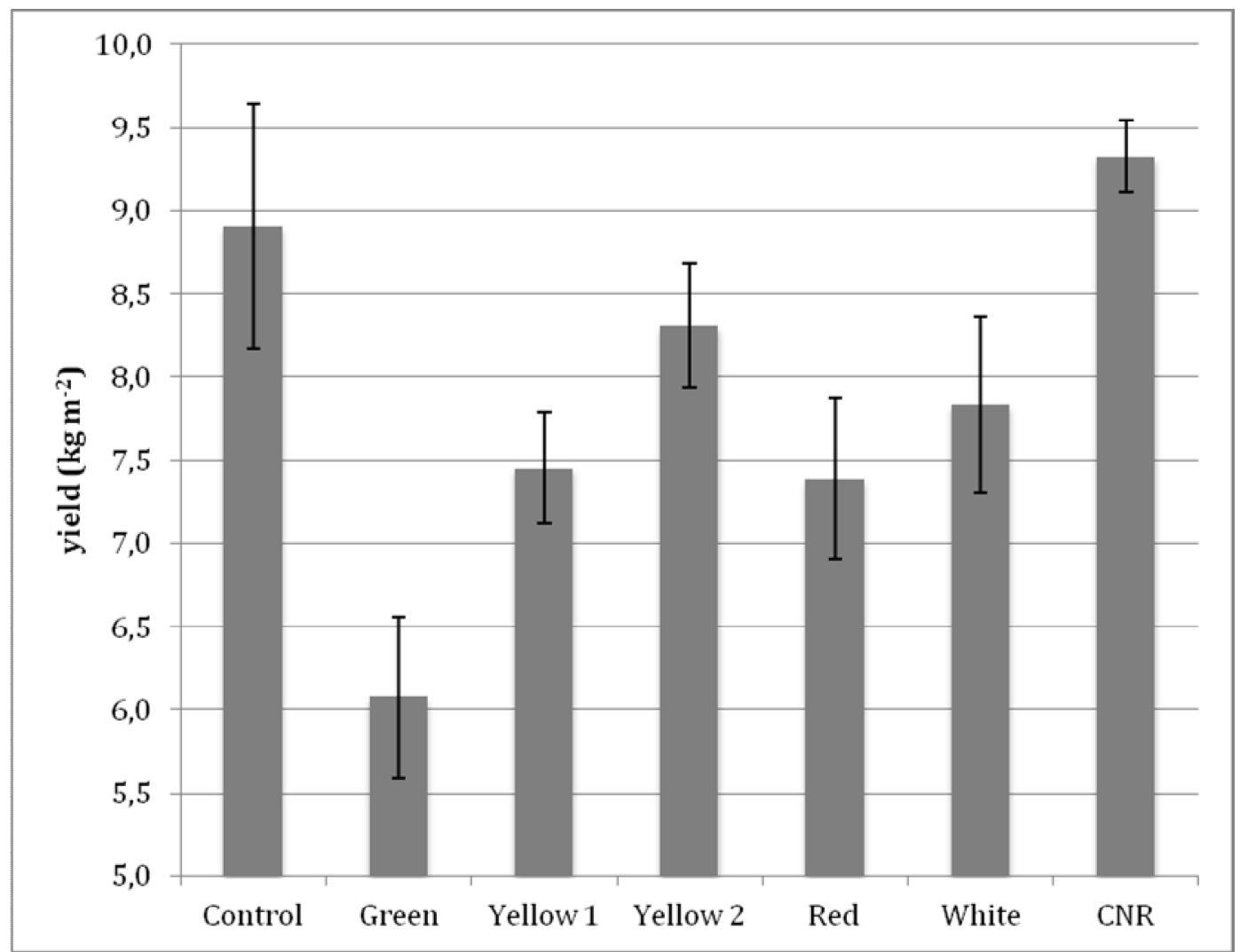

Figure 1. Total yield of sweet pepper varieties by colour shading nets in 2013

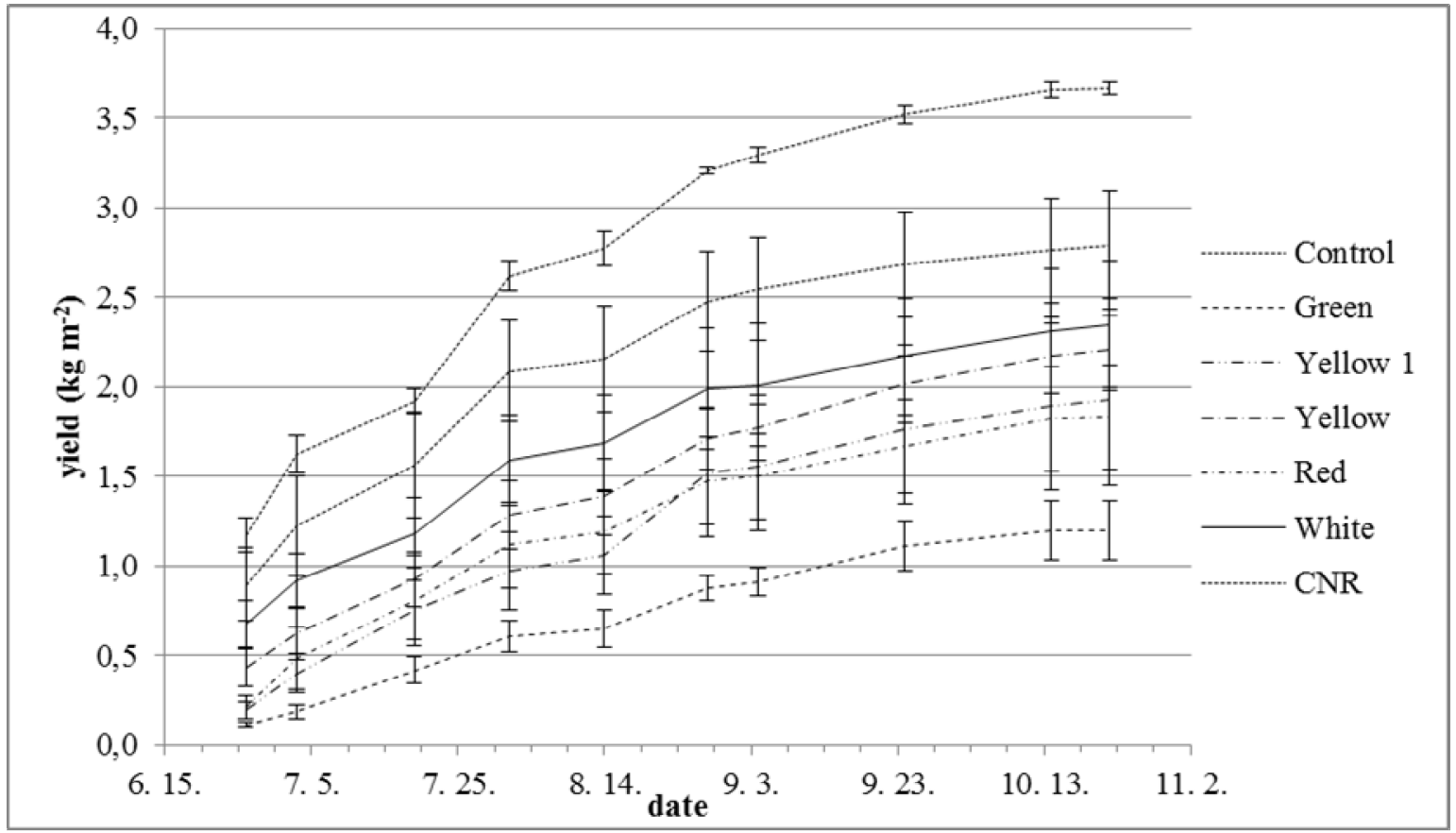

Figure 2. Total amount of extra class fruit quality of sweet pepper variety 'Galga' by colour shading nets produced in 2013 
Grower's income was calculated by shading colour nets based on the average pepper price according to the fruit quality gained in each harvest time in 2013 (Table 1). In spite of the outstanding fruit quality of pepper grown under yellow, red and CNR nets income was slightly higher compared to of control. The production and income was the least in the case of a tunnel covered with green net (Figure 3).

Table 1. Average pepper price used for income calculation

\section{Average pepper price given to grower (source DélKerTÉSZ)}

\begin{tabular}{l|cccccccccc} 
HUF/kg & 26 & 03 & 19 & 01 & 14 & 28 & 04 & 24 & 14 & 22 \\
& June & July & July & Aug. & Aug. & Aug. & Sept. & Sept. & Oct. & Oct. \\
\hline Extra & 176 & 178 & 210 & 122 & 90 & 120 & 150 & 182 & 252 & 278 \\
$\mathbf{1}^{\text {st }}$ class & 166 & 170 & 200 & 107 & 81 & 116 & 146 & 178 & 245 & 273 \\
$\mathbf{2}^{\text {nd }}$ class & 150 & 150 & 132 & 55 & 40 & 93 & 130 & 142 & 202 & 241
\end{tabular}

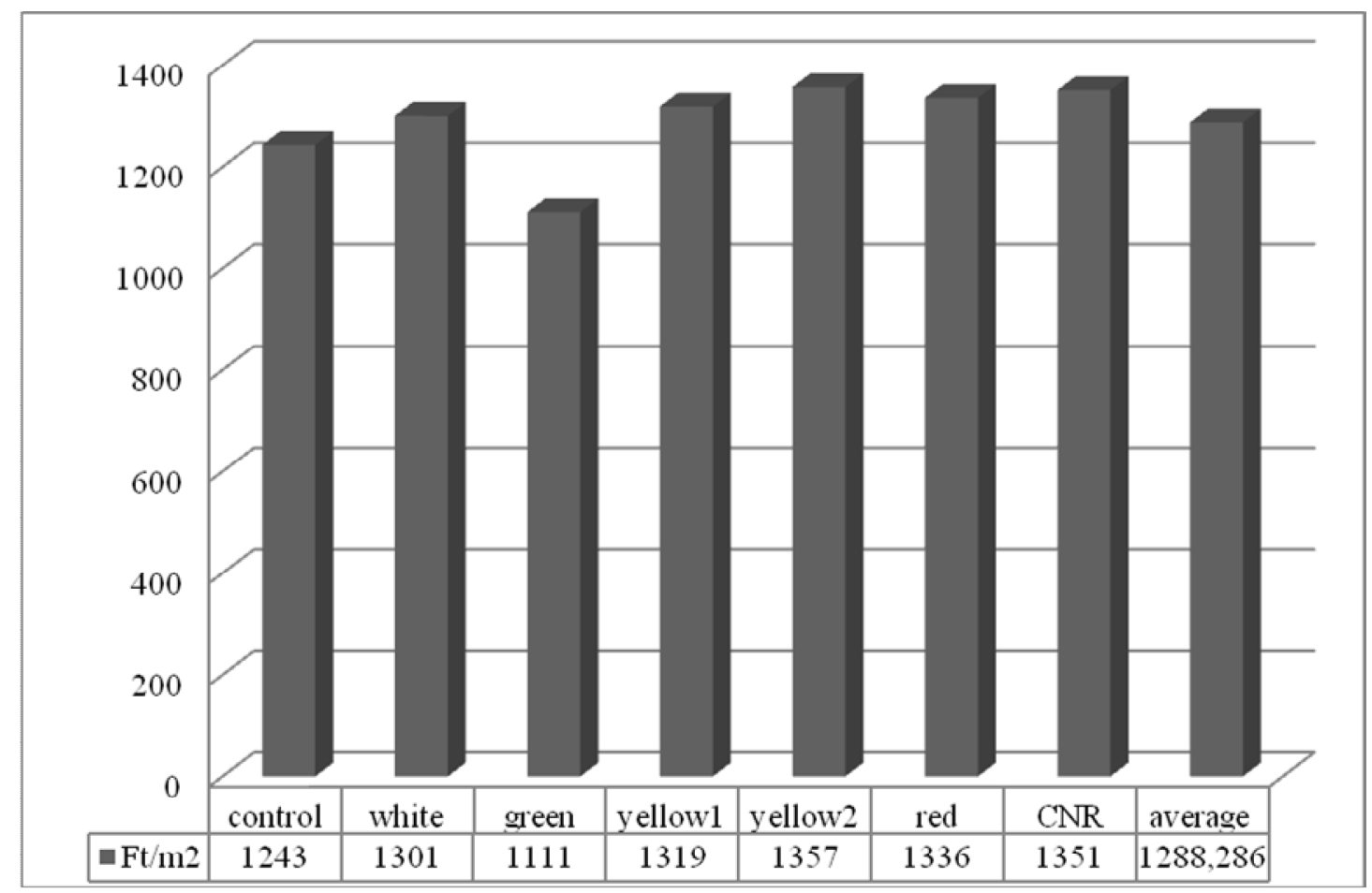

Figure 3. Average income of sweet pepper varieties by colour shading nets produced summer in 2013

\section{CONCLUSIONS}

The result of shading trial proved that using green colour shading net for ivory conical forced sweet pepper production will cause significant yield loss in homeland as it was published recently by KOVÁCS ET AL. (2011). The favourable effect of yellow1, yellow2, red and CNR colour shading nets for pepper production could not been proved in equally in this trial. ChromatiNet巴 ${ }^{\circledR}$ Red material having the higher shading intensity caused the higher yield. Numbers of fruits of extra quality had increased under yellow and red nets, as 
it was published according to FERREIRA ET AL. (2012), who had found increased pepper fruit quality found in size, weight and health of sweet pepper ripening to yellow and red colour under CNR.

As a conclusion, yellow and red colour shading nets can be offered for summer sweet pepper production in Hungary. Growers have to care the shading intensity of the net, which should not be higher than $35-40 \%$. Growers have to check and ask guarantees of UV and colour stability of shading materials before using. Colour shading nets can be placed onto the plastic tunnels just after the planting.

\section{ACKNOWLEDGEMENTS}

This study was supported by TÉSZ-ÉSZ Nonprofit Ltd., and co-financed by the TAMOP4.2.1.B-11/2/KMR-2011-0003 research project governed by Institute of Horticulture, Szent István University.

The author is thankful for the grower, Ferenc Hódi for the precise production.

\section{REFERENCES}

Ben-Yahir, D., Antignus, Y., Offir, Y., ShahaK, Y. (2012): Optical manipulations of insect pests for protecting agricultural crops. Acta Hort. 956: 609-613.

Ferreira, T.A.P.C., Valadares, K.O., Souza, M.J.F., Santana, J.Q., Balbino, M.P., FERREIRA, R.C. (2012): Yellow and red sweet pepper quality under photoselective screens and field crop conditions. Acta Hort. 956: 473-479.

GANELEVIN, R. (2008): World-wide commercial applications of colored shade nets technology (CromatiNet巴). Acta Hort. 770: 199-203.

IEPEREN, VAN W. (2012): Plant morphological and developmental responses to light quality in a horticultural context. Acta Hort. 956: 131-139.

Kong, Y., AVraham, L., Ratner K., ShahaK, Y. (2012): Response of photosynthetic parameters of sweet pepper leaves to light quality manipulation by photoselective shade nets. Acta Hort. 956: 501-506.

KovÁcs, A., TÓTHNÉ, T.Z., HRAsKó, I. LEDÓNÉ, D.H., KÖHÁZI-KISS, A. (2011): Különféle árnyékolási módok vizsgálata vándorfóliás paprikahajtatásban. AGTEDU 2011. XII. Nemzetközi Tudományos Konferencia, 2011. november 10. Kecskeméti Főiskola. 65-68.p. KovÁCS, A. (2012): Árnyékoló anyagok (hálók) fényáteresztő képességének vizsgálata. Kutatási jelentés- TÉSZ-ÉSZ Nonprofit Kft.

LEDÓNÉ, D. H. (2011): A vándorfólia alatti paprikatermesztés tapasztalatai. ZöldségGyümölcs Piac és Technológia 8:10-12.

Ledóné, D.H., PÉK, Z., Szuvandzsiev, P., OMBÓdi, A., Helyes, L. (2013): Effect of different colour of shading nets on spectral reflectance and SPAD values on 'Capia' type red sweet pepper leaves. 389-401 p. Proceedings of the EUCARPIA Meeting on Genetics and Breeding of Capsicum and Eggplant 2-4. September 2013, Torino-Italy.

Santana, J.O., Balbino, M.A., TAVares, T.R., Bezerra, R.S., FArias, J.G., Ferreira, R.C. (2012): Effect of photoselective screens in the development and productivity of red and yellow sweet pepper. Acta Hort. 956: 493-500.

ShaHAK, Y. Gussakovsky, E.E., Gal, E., Ganelevin, R. (2004): ColorNets: Crop protection and light-quality manipulation in one technology. Acta Hort. 659: 143-151. 
434

Review on Agriculture and Rural Development 2014. vol. 3 (2) ISSN 2063-4803

ShahaK, Y., GAL,E., OfFIR, Y., Ben-YYAKIR, D. (2008): Photoselective shade netting integrated with greenhouse technologies for improved performance of vegetable and ornamental crops. Acta Hort. 797:75-80.

ShahaK, Y., OffiR, Y., Matan, E., Yehezkel, H., Messika, Y., Posalski, I., Ben-YaKiR, D. (2009): Photoselective netting: an emerging approach in protected agriculture. Acta Hort. 807: 79-84.

http1:

http://www.met.hu/eghajlat/magyarorszag_eghajlata/eghajlati_visszatekinto/elmult_evek_i dojarasa/ 